\title{
19. PETROLOGY OF BASALT RECOVERED DURING DSDP LEG 39B
}

\author{
R.V. Fodor, J.W. Husler, and K. Keil, Department of Geology and Institute of Meteoritics, \\ University of New Mexico, Albuquerque, New Mexico
}

\begin{abstract}
Basaltic basement rock ( $7.5 \mathrm{~m}$ core; $78.1 \pm 9 \mathrm{~m} . \mathrm{y}$. old) from the Brazil Basin, and a basaltic pebble in a Cretaceous chalk from the São Paulo Plateau were recovered during Leg 39B. Brazil Basin basalt is typical ocean-ridge tholeiite and is characterized by intergranular plagioclase (Anss-si), clinopyroxene (mainly augite), and titaniferous magnetite, and low bulk $\mathrm{K}_{2} 0$ content $(0.07 \mathrm{wt} \%$ in the freshest sample); relict olivine is also present in the upper, more altered core samples. Compositional changes attributable to seawater alteration are higher $\mathrm{K}_{2} \mathrm{O}$ (and possibly $\mathrm{Cr}$ ) and lower $\mathrm{Ni}$ contents when comparing the lowermost (freshest) to uppermost (most altered) core samples.

The basaltic pebble from the São Paulo Plateau is extremely altered, but high $\mathrm{K}_{2} \mathrm{O}$ in feldspar, and interstitial alkali feldspar indicate that it may represent oceanic alkalic basalt or alkalic basalt transitional to tholeiite. It was probably derived by slump from the São Paulo Ridge, which, based on the pebble's composition, may be composed of former oceanic islands bordering the São Paulo Plateau.
\end{abstract}

\section{INTRODUCTION}

Basaltic basement rock was recovered from the Brazil Basin, Site 355, during Leg 39B (Figure 1). This material was located between magnetic anomalies 33 and 34 (Pitman et al., 1975) and is the oldest basaltic unit cored from the South Atlantic Ocean (78.1 \pm 9 m.y.; McKee and Fodor, this volume). The 7.5 meter core length provides an opportunity to describe petrologic characteristics with reference to both vertical variation within the core and to younger oceanic basalt located closer to the Mid-Atlantic Ridge. This report presents the detailed chemistry and mineralogy of basalt samples at four vertical intervals throughout the core.

Drilling on the São Paulo Plateau, Site 356 (Figure 1) (near the São Paulo Ridge), yielded a basaltic pebble $(\sim 3 \mathrm{~cm})$ from a Cretaceous marly chalk. A petrologic description of this material is also presented to help characterize the type of basaltic material present in the São Paulo plateau region.

\section{ANALYTICAL PROCEDURES}

Whole-rock analyses of basalt were obtained by the following techniques: Silica was determined gravimetrically. Total $\mathrm{Fe}, \mathrm{Al}_{2} \mathrm{O}_{3}, \mathrm{MgO}, \mathrm{CaO}, \mathrm{Na}_{2} \mathrm{O}$, $\mathrm{K}_{2} \mathrm{O}, \mathrm{TiO}_{2}$, and $\mathrm{MnO}$ were determined by atomic absorption using calibration curves prepared from U.S. Geological Survey standard basalt, BCR-1. For determination of $\mathrm{P}_{2} \mathrm{O}_{5}$, an adaptation of the Molybdenum Blue spectrophotometric method was employed. Water was determined by ignition loss, but the amount of $\mathrm{Fe}$ oxidation was taken into account by $\mathrm{K}_{2} \mathrm{Cr}_{2} \mathrm{O}_{7}$ titration of ferrous iron in both the ignited and unignited sample. The trace elements $\mathrm{Rb}, \mathrm{Ba}, \mathrm{Sr}$, $\mathrm{Co}, \mathrm{Cr}, \mathrm{Ni}$, and $\mathrm{V}$ were also determined by atomic absorption, using larger sample weights than for the major elements. Mineral compositions were determined with an ARL-EMX-SM electron microprobe operated at $15 \mathrm{keV}$ accelerating voltage and 0.015 to $0.020 \mu \mathrm{A}$ sample current. Corrections for differential matrix effects were made according to Bence and Albee (1968).

\section{GENERAL DESCRIPTIONS}

Basalt in the Brazil Basin was reached about 450 meters below the sea floor in 4900 meters water depth. The contact between basalt and overlying sediment was not recovered nor was the basalt drilled extensively enough to indicate whether it is a sill or true basement.

The upper $10 \mathrm{~cm}$ of the core ranges in color from dark gray to yellowish-gray and consists almost entirely of clay minerals produced by seawater alteration. The remaining portion of the core is medium to dark gray in color and highly fractured and veined with calcite. At least four altered, glassy zones were observed and these may represent the tops of separate flows. They are generally thin $(\leq 1 \mathrm{~cm})$ and often mixed with calcite. Local brecciated zones are sometimes associated with the altered glass. The basalt is essentially aphyric, although plagioclase laths are visible in certain areas.

At the São Paulo Plateau, a sedimentary marly chalk containing a basaltic pebble was cored at about 660 meters below the sea floor in about 3175 meters water depth. The pebble is about $3.5 \mathrm{~cm}$ long and $2 \mathrm{~cm}$ thick, 


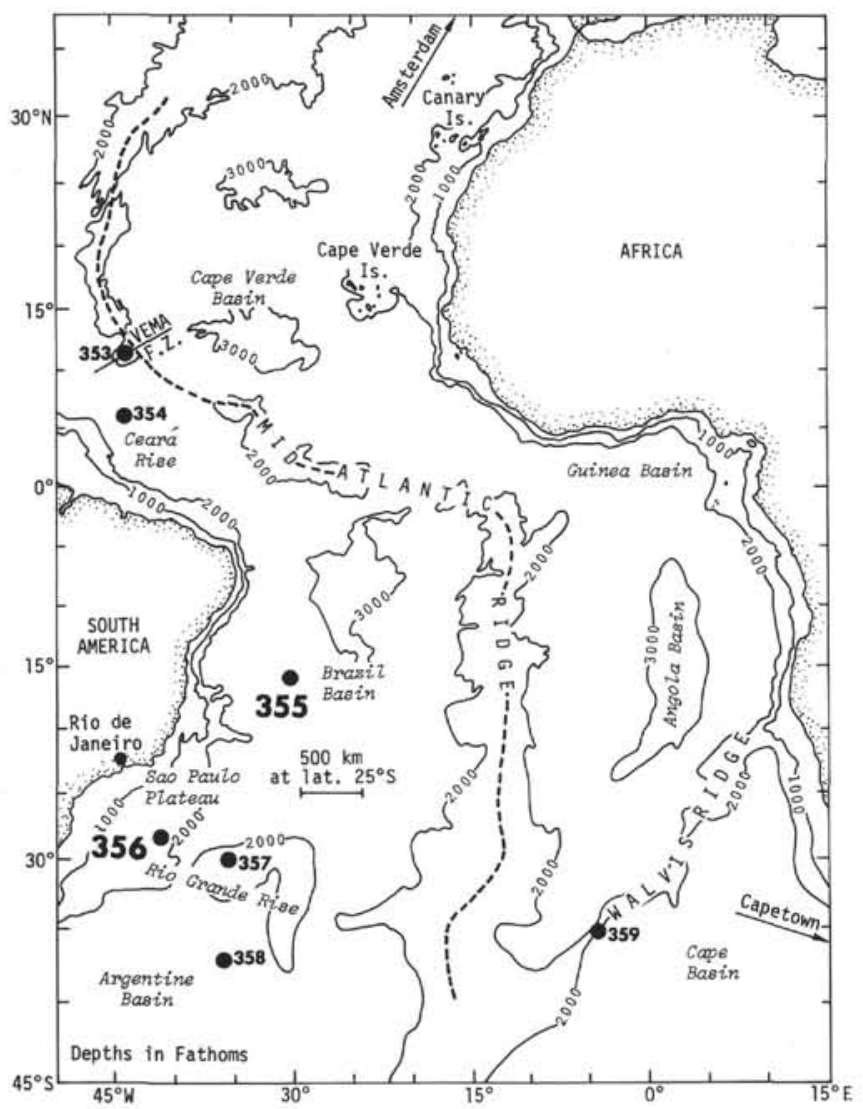

Figure 1. Map of the South Atlantic Ocean showing the locations of Sites 355 and 356, and other sites drilled during Leg 39.

dark gray in color, and contains phenocrysts of oxidized olivine (reddish in color), clinopyroxene, and plagioclase. A distinct weathering rim about $5 \mathrm{~mm}$ thick is visible in a cut cross-section. The pebble was recovered from a core of Santonian (Cretaceous) marly calcareous chalk containing black shale and Inoceramus fragments. Altered basaltic pebbles $(0.2 \mathrm{~mm}$ to $1 \mathrm{~cm}$ ) were also observed in conglomeratic zones, mudstones, and graded zones lying 20 to 50 meters below the pebble, indicating extensive deposition of coarse material during Santonian time, presumably by slump from a nearby ridge (Figure 2).

\section{PETROGRAPHY}

Thin-section examination of the Brazil Basin basalt reveals a large range in the degree of alteration; the freshest samples with closest to original textures are from near the base of the core. Texture is intergranular and consists of plagioclase phenocrysts, microphenocrysts, and groundmass laths ( $1 \mathrm{~mm}$ to $0.1 \mathrm{~mm}$ ) intimately associated with microphenocrysts and groundmass clinopyroxene $(0.4$ to $0.1 \mathrm{~mm}$ ) (Figure 3 ); they sometimes occur in glomerocrysts, or clots (Figure 4). In the upper half of the core, most of the groundmass pyroxene has been altered to brownish clay minerals and highly oxidized remnants of olivine are present as rare phenocrysts. No olivine was observed in the lower parts of the core. Present in the groundmass of the lowermost and freshest core samples are angular, sometimes skeletal, oxides $(\sim 0.05 \mathrm{~mm})$, but they are absent from the more altered upper core. Crystallization of clinopyroxene in part preceded plagioclase as indicated by some microphenocrysts of pyroxene enclosed by feldspar (Figure 5). Where olivine remnants are present, it may have been the liquidus phase. Plagioclase appears to have been the phase most resistant to alteration as indicated by the presence of at least a few remaining laths even in the most intensely altered samples.

A thin section of the São Paulo Plateau basaltic pebble shows an extreme alteration of the original texture that probably consisted of intergranular feldspar and clinopyroxene. Present now are plagioclase laths, oxides, and clay minerals forming the groundmass and phenocrysts of plagioclase, clinopyroxene, and highly oxidized relict olivine (Figure 6). Of the plagioclase and clinopyroxene phenocrysts, grain margins are altered, but fresh cores remain.

\section{BULK COMPOSITION}

Whole-rock analyses and normative mineralogy of four samples from the Brazil Basin basalt core are presented in Table 1. Areas of the core sampled for analyses are illustrated in Figure 7; systematic sampling, however, was hampered somewhat by fractures, veins, and secondary mineralization present in the core.

Samples throughout the core are remarkably similar in major element concentrations, indicating that the entire core either represents one flow or, more likely, several flows from the same source. There is variation, however, in $\mathrm{K}_{2} \mathrm{O}$ content, where a very low $(0.07 \mathrm{wt} \%)$ concentration is present in the lowermost sample (22-5) and values closer to $0.5 \mathrm{wt} \%$ are measured higher in the core. Because samples farthest from the basaltsediment interface are expected to be least affected by seawater alteration, the low $\mathrm{K}_{2} \mathrm{O}$ of the bottom sample is probably closest to the original concentration, whereas higher $\mathrm{K}_{2} \mathrm{O}$ contents in the upper samples probably resulted from seawater alteration (Hart, 1970; Hart et al., 1974). This is in agreement with textural observations, but curiously, is not apparent from $\mathrm{H}_{2} \mathrm{O}$ contents (Table 1); the bottom sample has more $\mathrm{H}_{2} \mathrm{O}$ than the highly altered upper core samples.

Trace element contents (Table 1) show a general trend of increasing $\mathrm{Cr}$ and decreasing $\mathrm{Ni}$ and $\mathrm{V}$ contents from the bottom to the top of the core (freshest to most altered); V, however, greatly increases again near the top. The change in $\mathrm{Ni}$ agrees with data reported by others for the alteration effects in basalts (e.g., Hart et al., 1974), but nothing conclusive is known about the changes in $\mathrm{Cr}$ and $\mathrm{V}$ contents. Here, changes in $\mathrm{V}$ may be related to weathering of titaniferous magnetite in the upper samples, as opposed to primary fractionation, whereas there is no apparent reason attributable to weathering for the $\sim 20 \%$ increase in $\mathrm{Cr}$.

Comparison of bulk compositions to those of dredged Mid-Atlantic Ridge basalts shows that the Brazil Basin core is typical mid-ocean ridge basalt 


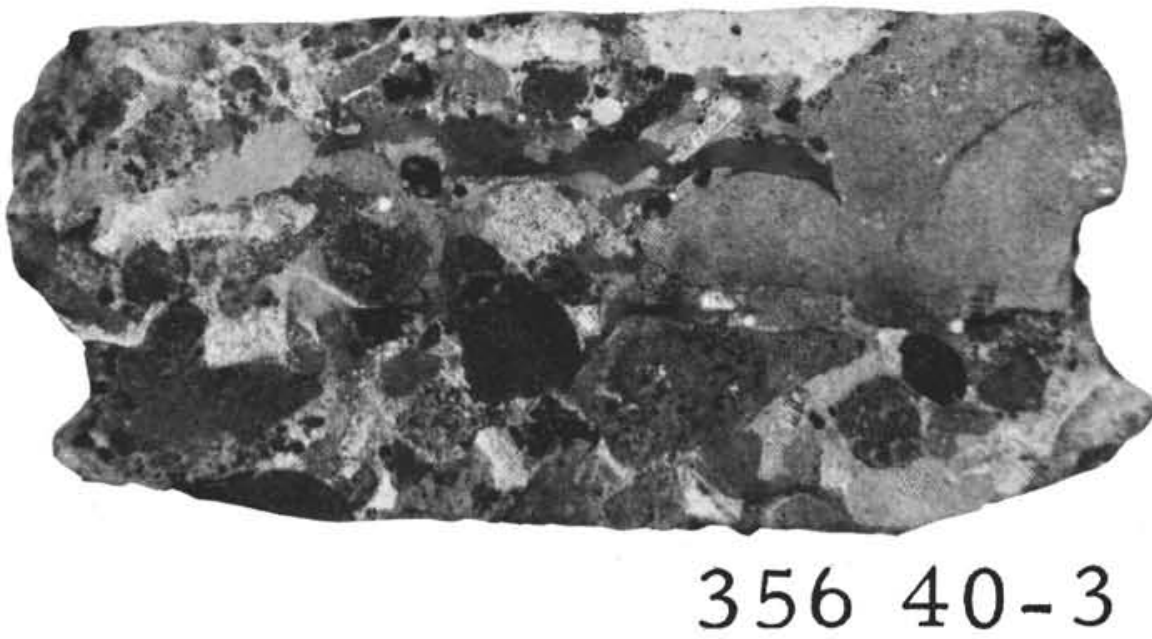

Figure 2. A Cretaceous conglomerite composed partly of basaltic fragments from the São Paulo plateau. This sample is from one of many conglomeratic zones that the basaltic pebble (356-38-378) is associated with. Scale is provided by the typewritten numbers. Photo provided by J. Thiede.

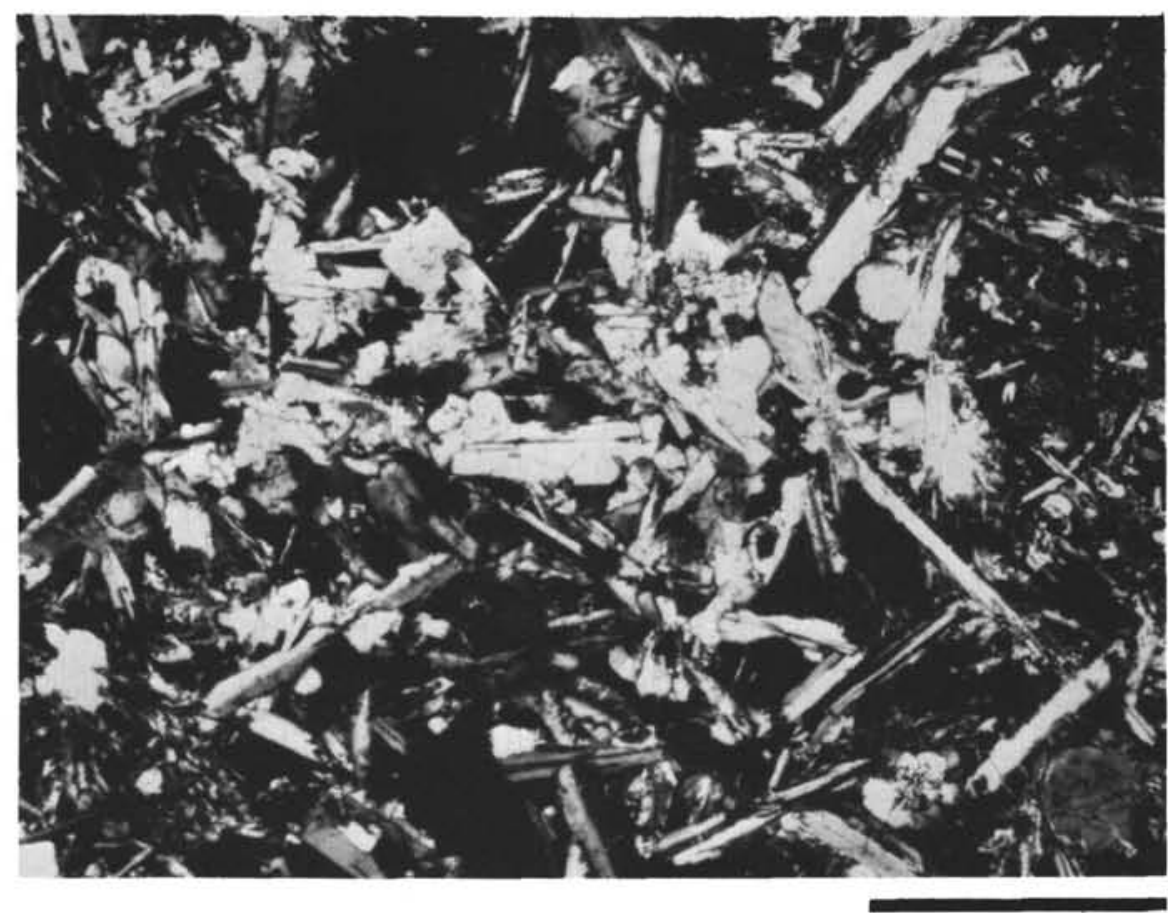

Figure 3. Intergranular texture of plagioclase and clinopyroxene in the Brazil Basin basalt (22-5). Crossed nicols; scale bar equals $0.5 \mathrm{~mm}$.

(Table 1). Unlike many oceanic tholeiites, however, the Brazil Basin basalts are highly quartz normative (Table 1; Figure 8), but this characteristic is largely the result of the degree of oxidation (i.e., $\mathrm{Fe}_{2} \mathrm{O}_{3} / \mathrm{FeO}$ ). When normative mineralogy is calculated after normalizing $\mathrm{Fe}_{2} \mathrm{O}_{3}$ to 1.5 wt $\%$ and omitting $\mathrm{CO}_{2}$, there is a compositional shift into or closer to the field of olivine tholeiites (Figure 8). This is consistent with the relict olivine observed in the uppermost samples. Relatively low $\mathrm{P}_{2} \mathrm{O}_{5}, \mathrm{TiO}_{2}, \mathrm{Rb}, \mathrm{Ba}$, and $\mathrm{Sr}$ contents also characterize the Brazil basalt as ocean-ridge basalt (Table 1).
The São Paulo basalt pebble is highly altered as indicated by exceedingly high $\mathrm{H}_{2} \mathrm{O}(6.5 \mathrm{wt} \%)$ and $\mathrm{CO}_{2}$ contents (Table 1). This presents difficulty in establishing the true character of the basalt, whether tholeiitic or alkalic. Some oxide contents, such as low $\mathrm{SiO}_{2}$ and high $\mathrm{K}_{2} \mathrm{O}$, suggest that the pebble has alkalic characteristics, although they are not entirely conclusive because alteration of ocean-ridge tholeiite can result in material that closely resembles true oceanic alkalic-basalt in composition (Hart, 1970). The high $\mathrm{K}_{2} \mathrm{O}$ content, however, appears too high to have resulted from an alteration of low-K (tholeiitic) 


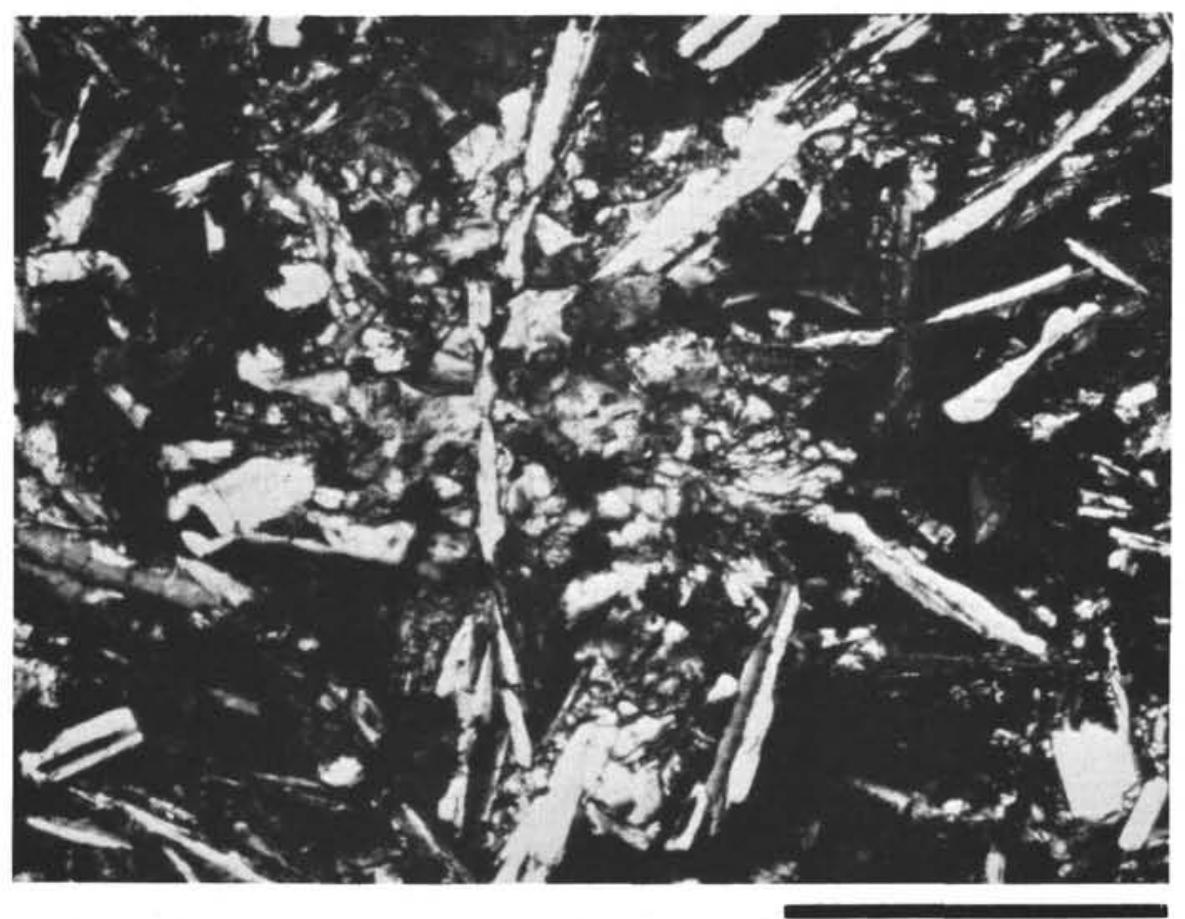

Figure 4. A cluster, or glomerocryst, of plagioclase and clinopyroxene in the Brazil Basin basalt (22-5). Crossed nicols; scale bar equals $0.5 \mathrm{~mm}$.

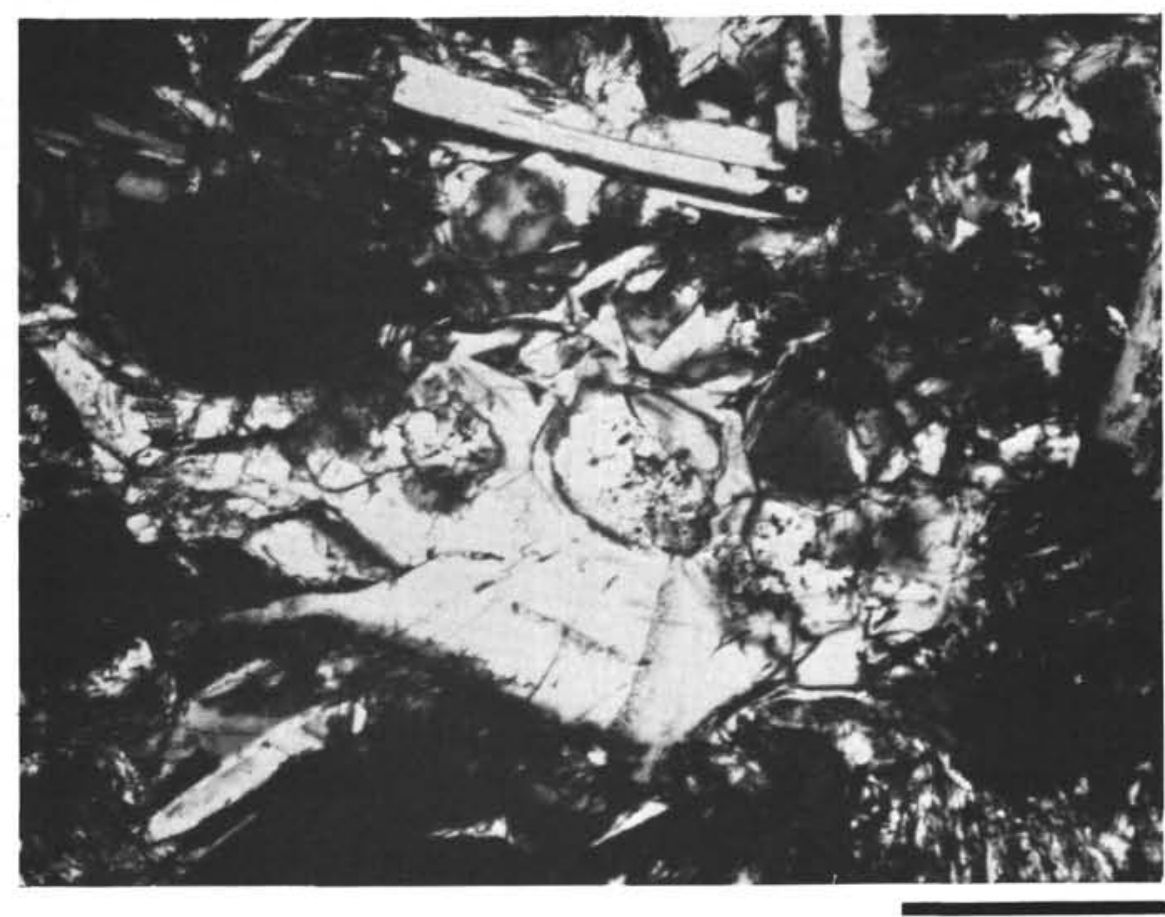

Figure 5. Clinopyroxene enclosed by plagioclase in the Brazil Basin basalt (22-2). Crossed nicols; scale bar equals $0.2 \mathrm{~mm}$.

material. For example, Bass et al. (1973) showed analyses of highly altered basalts with 4.7 and $6.5 \mathrm{wt} \%$ $\mathrm{H}_{2} \mathrm{O}$ that contain only about 0.5 wt $\% \mathrm{~K}_{2} \mathrm{O}$. Also, Matthews (1971) showed that alteration of an oceanic basalt $\left(7.2\right.$ wt $\left.\% \mathrm{H}_{2} \mathrm{O}\right)$, which is comparable in alteration to that of the São Paulo pebble, increased $\mathrm{K}_{2} \mathrm{O}$ by about three times initial $\mathrm{K}_{2} \mathrm{O}$ content. In comparison, to account for $\mathrm{K}_{2} \mathrm{O}$ of $2.5 \mathrm{wt} \%$ in the pebble from an original $\mathrm{K}_{2} \mathrm{O}$ of $<0.5$ wt \% (tholeiitic) would require an increase by about five times. 


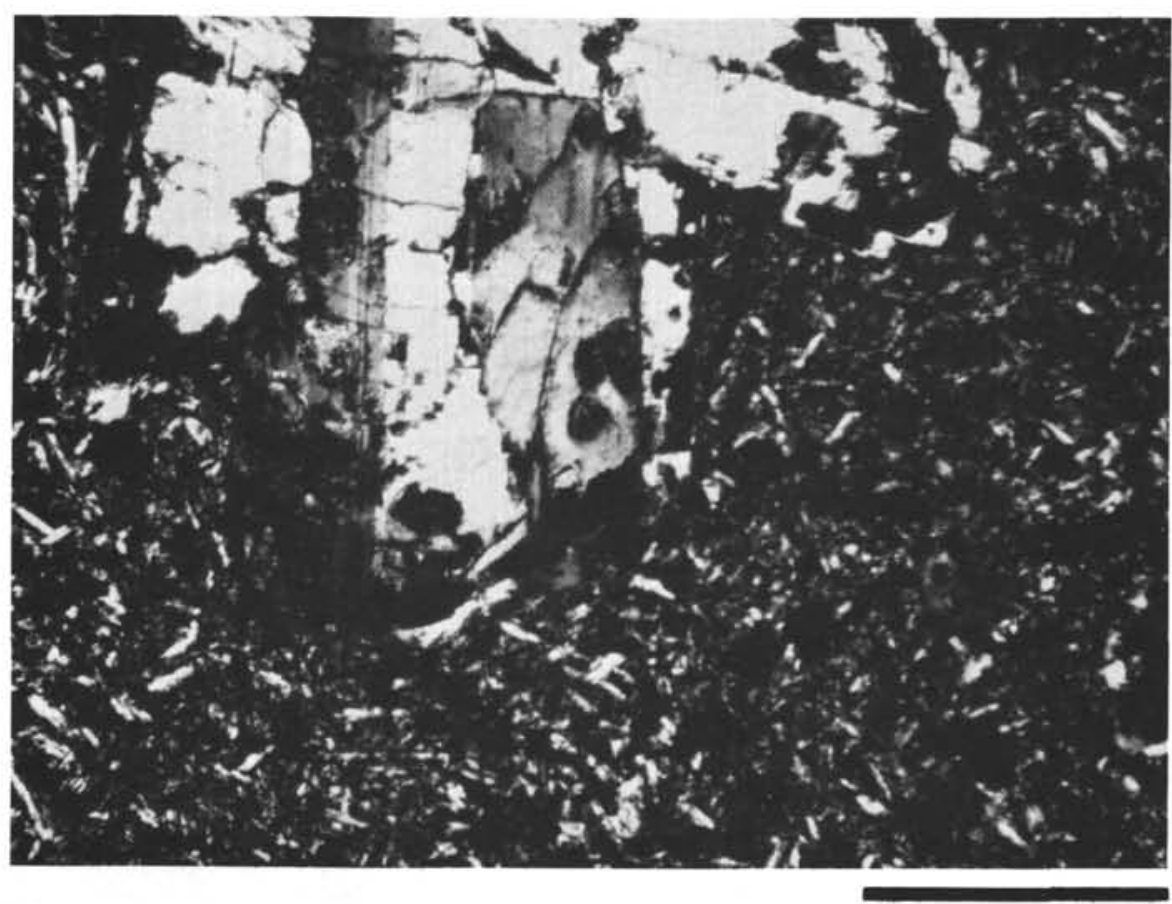

Figure 6. Plagioclase phenocrysts with corroded margins in the highly altered basaltic pebble from the São Paulo plateau. Groundmass consists of clay minerals and plagioclase laths. Crossed nicols; scale bar equals $1 \mathrm{~mm}$.

Although alteration effects cannot be expected to produce the same results everywhere, the changes in $\mathrm{K}_{2} \mathrm{O}$ contents due to alteration observed in other rocks make it seem unlikely that the basaltic pebble was originally tholeiitic. High $\mathrm{Rb}, \mathrm{Sr}$, and $\mathrm{Ba}$ in the pebble possibly also represent true alkalic-basalt concentrations (Table 1). Although $\mathrm{Rb}$ and $\mathrm{Ba}$ concentrations increase with seawater alteration, they are not known to increase more than a few parts per million under moderate alteration (Hart et al., 1974).

Normative mineralogy has substantial quartz (Table 1; Figure 8), but that is largely a function of high $\mathrm{Fe}_{2} \mathrm{O}_{3} / \mathrm{FeO}$. When $\mathrm{Fe}_{2} \mathrm{O}_{3}$ is normalized to 1.5 wt $\%$ and $\mathrm{CO}_{2}$ omitted, the composition is much closer to the plane of undersaturation (O1-Di of Figure 8).

\section{MINERALOGY}

Mineral compositions were determined in three of the four bulk compositionally analyzed Brazil Basin basalt samples, representing top, middle, and bottom portions of the core, and for the São Paulo basaltic pebble.

\section{Clinopyroxene}

Microphenocrysts and groundmass clinopyroxene are present in each of the sections analyzed of the Brazil Basin basalts, although intense alteration of the top sample, 21-1, left only rare and exceedingly small $(\sim 1$ to $2 \mu \mathrm{m}$ ) grains. One phenocryst was also observed in 21-1. Average compositions (Table 2) and the compositional trend (Figure 9) of increasing $\mathrm{FeO}$ and $\mathrm{MnO}$ attended by a decrease in $\mathrm{CaO}$ and $\mathrm{SiO}_{2}$ from phenocryst, to microphenocryst, to groundmass are similar to those of clinopyroxene typically found in tholeiitic basalts (Fodor et al., 1975). Throughout the core, there are no significant compositional differences in clinopyroxene. Compositional zoning occurs in the microphenocrysts, and groundmass pyroxene is highly variable with respect to $\mathrm{Fe}$ and $\mathrm{Ca}$ (Figure 9). Groundmass compositions presented for 21-1, however, are subject to some question because of intense alteration in this sample and difficulty in avoiding overlap onto clay minerals with the electron beam when analyzing the small grains of remaining pyroxene.

Attending the changes in grain size from phenocryst to groundmass clinopyroxene, there is a substantial increase in $\mathrm{TiO}_{2}$ (Figure 10). Between microphenocrysts and groundmass, $\mathrm{Al}_{2} \mathrm{O}_{3}$ content is nearly constant or appears to decrease slightly with increasing $\mathrm{TiO}_{2}$, as illustrated by the freshest sample, 22-5 (Figure 10, Table 2) (the high $\mathrm{Al}_{2} \mathrm{O}_{3}$ values shown for 21-1 may be due to particularly high alteration in that sample). A slight decrease in $\mathrm{Al}_{2} \mathrm{O}_{3}$ probably reflects simultaneous crystallization of groundmass pyroxene and plagioclase. The increase in $\mathrm{TiO}_{2}$ from microphenocryst to groundmass indicates that titaniferous magnetite probably crystallized after groundmass pyroxene; this is also suggested by texture.

Fresh cores of otherwise altered clinopyroxene phenocrysts in the São Paulo basalt pebble (Table 2; Figure 9) have compositions (Fsı ${ }_{11} n_{49} W_{O_{40}}$ ) common to pyroxene phenocrysts in tholeiitic basalt. This composition, however, is also observed for some alkalic basalts and alkalic basalts transitional to tholeiites (Fodor et al., 1975). 
R.V. FODOR, J.W. HUSLER, K. KEIL

TABLE

Bulk Compositions and Molecular Norms of Four Brazil Basin Basalt Samples (Columns 1-4; Top to Bottom of Core; Figure 7) and a Basaltic Pebble from the Sao Paulo Plateau (Column 5), Western South Atlantic Ocean, Compared to Average Compositions of 33 and 6 Dredged MAR Basalts (Columns 6, 7; after Melson and Thompson, 1971, and Kay et al., 1970, Respectively)

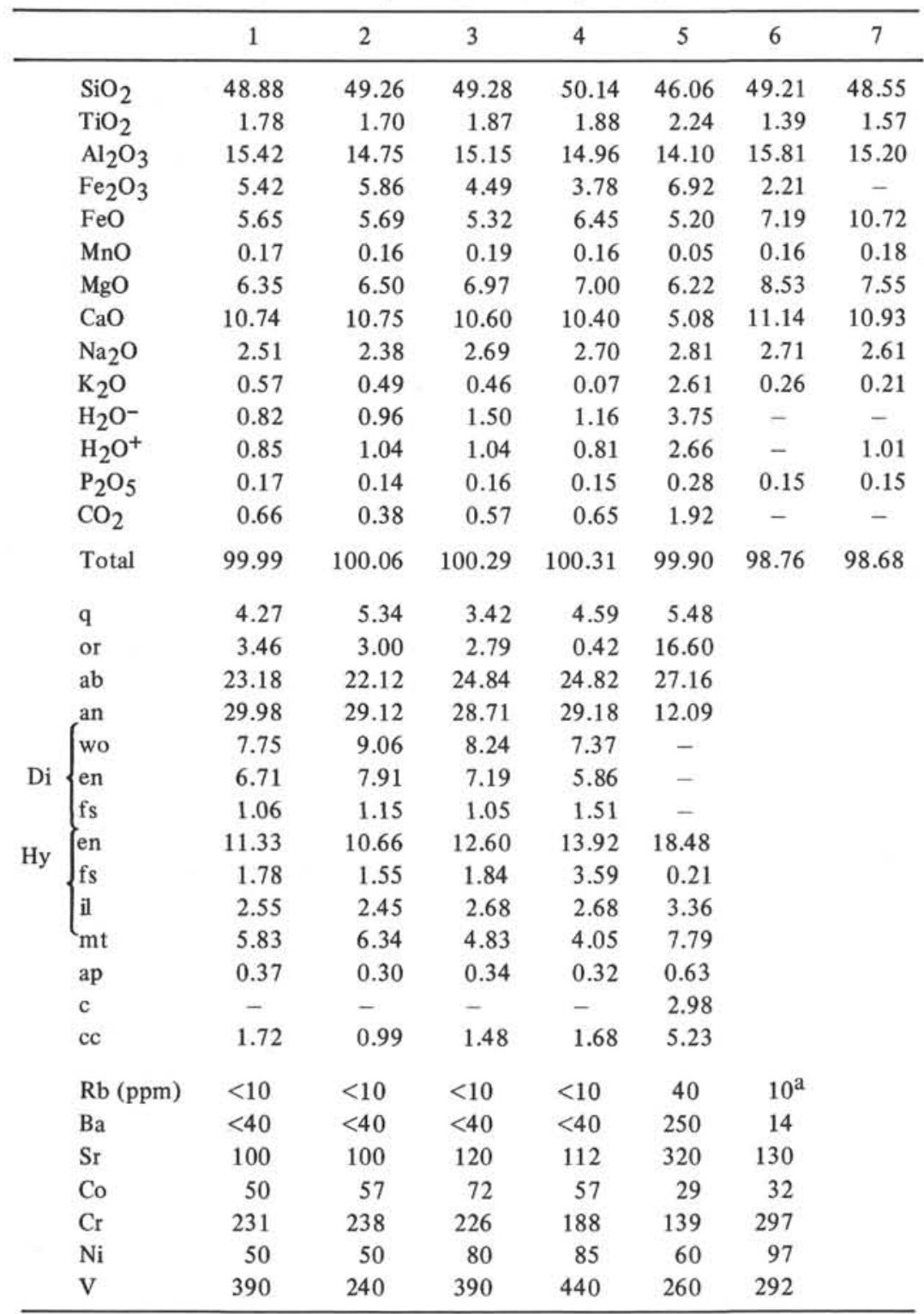

Note: DSDP sample numbers; Column 1, 355-21-1, $102 \mathrm{~cm}$; Column 2, 35522-2, $44 \mathrm{~cm}$; Column 3, 355-22-3, $12 \mathrm{~cm}$; Column 4, 355-22-5, $120 \mathrm{~cm}$; Column $5,356-38-8,78 \mathrm{~cm}$.

${ }^{\text {a }}$ Average for tholeiitic basalts; after Engel et al. (1965).

\section{Feldspar}

Phenocrysts, microphenocrysts, and groundmass feldspar in the Brazil Basin basalt (Table 3; Figure 11) range in composition from calcic bytownite to sodic labradorite and are exceedingly low in $\mathrm{K}_{2} \mathrm{O}$ contents $(<0.11 \mathrm{wt} \%)$. Compositional changes from phenocryst to groundmass include an increase in $\mathrm{Na}_{2} \mathrm{O}, \mathrm{K}_{2} \mathrm{O}, \mathrm{FeO}$, and $\mathrm{SiO}_{2}$ and a decrease in $\mathrm{Al}_{2} \mathrm{O}_{3}$, whereas $\mathrm{MgO}$ remains nearly constant. No high-K rims on large feldspar grains nor interstitial material were observed. All of these features are characteristic of feldspar in tholeiitic basalts (Keil et al., 1972).

Fresh cores in phenocrysts of the São Paulo basalt pebble are also bytownite in composition, but higher in $\mathrm{K}_{2} \mathrm{O}$ relative to feldspar in the Brazil Basin basalt (Table 3). The groundmass feldspar is labradorite in composition and higher in $\mathrm{K}_{2} \mathrm{O}$ relative to labradorite in the Brazil Basin basalt. Most notably, there is interstitial material in the groundmass very high in $\mathrm{K}_{2} \mathrm{O}$ 


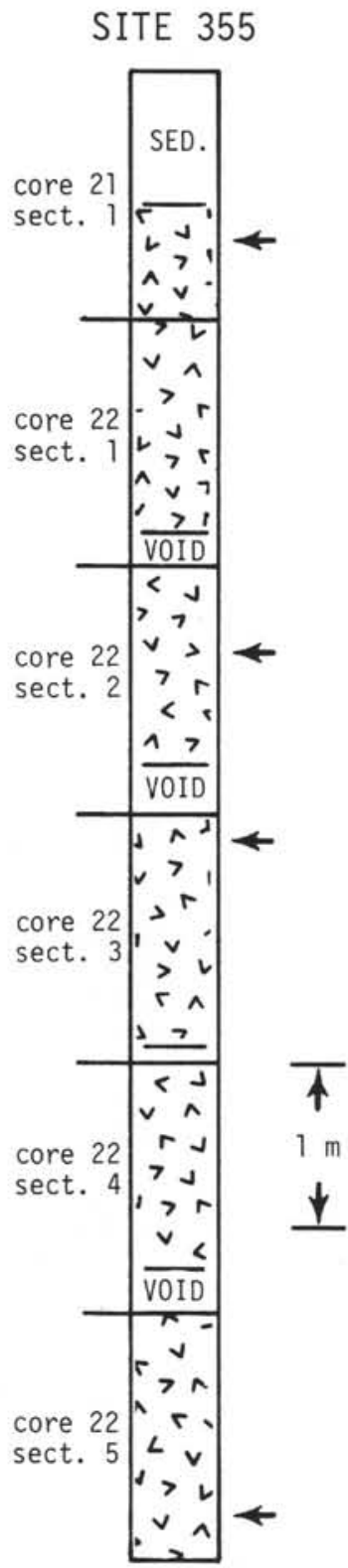

Figure 7. Schematic diagram showing the sampling areas (arrows) in the Brazil Basin basalt core.

content, some reaching $\mathrm{An}_{2} \mathrm{Ab}_{10} \mathrm{Or}_{88}$. The presence of $2.1 \mathrm{wt} \%$ Or end member in the groundmass laths and the high-K interstitial material are characteristic for alkalic basalt (Keil et al., 1972). Whether or not the enrichment in $\mathrm{K}$ in the feldspar is innate or a result of the intense alteration is essential to interpreting the true character of the rock. Seawater alteration increases the $\mathrm{K}$ content of basaltic material by forming clay minerals (Melson and Thompson, 1973) and K-feldspar cores in plagioclase, but to have $\mathrm{K}$ enter plagioclase without obvious alteration (optically, the plagioclase cores appear fresh) and to form interstitial material that is stoichiometrically high-K feldspar seems highly unlikely. Although replacement of plagioclase by stoichiometric orthoclase has occurred in deep-sea basalts (Matthews, 1971; Bass et al., 1973; Steward et al., 1973), no incipient or partial alteration, such as

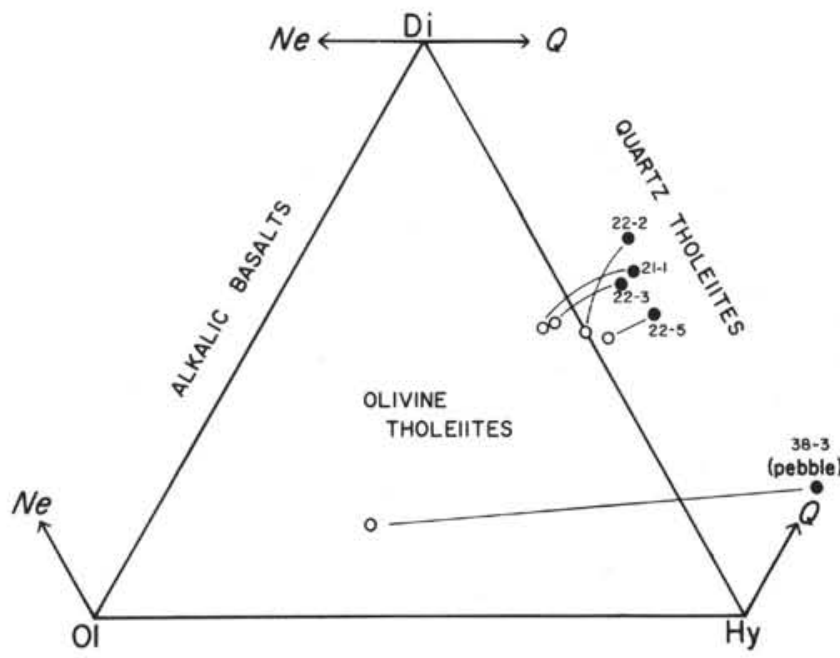

Figure 8. Normative mineralogy plotted on a diopside (Di)hypersthene (Hy)-olivine (01)-quartz (Q)-nepheline (Ne) diagram. Closed circles represent norms listed in Table 1 and open circles represent norms recalculated after $\mathrm{CO}_{2}$ is omitted and $\mathrm{Fe}_{2} \mathrm{O}_{3}$ normalized to $1.5 \mathrm{wt} \%$.

only a small $\left(<1.0\right.$ wt \%) increase in $\mathrm{K}_{2} \mathrm{O}$ throughout plagioclase, has been reported. Therefore, the alkalic characteristics of the feldspar and interstitial material are thought to be real.

The coexistence of pyroxene having tholeiitic affinities and feldspar that is typically alkalic has previously been reported for a Hawaiian tholeiite that was classified by Keil et al. (1972) and Fodor et al. (1975) as transitional between tholeiitic and alkalic basalt. On the basis of pyroxene and feldspar compositions, the São Paulo pebble may be a basalt transitional between tholeiitic and alkalic basalt, but highly altered by seawater.

\section{Oxides}

The only oxide present in the Brazil Basin basalt is titaniferous magnetite in the lowermost portion of the core (22-5). Its composition (Table 4) is similar to that of titaniferous magnetite in other tholeiitic basalts, such as of Hawaii (Fodor et al., 1972).

In the São Paulo basalt pebble, titaniferous magnetite and ilmenite coexist, both as individual grains and in the same grain (Table 4). The ulvöspinel content of the magnetite is lower than that of magnetite in the Brazil Basin basalt. Equilibration temperature and oxygen fugacities estimated from the coexisting $\mathrm{Fe}$ $\mathrm{Ti}$ oxides (Buddington and Lindsley, 1964) are $925^{\circ} \mathrm{C}$ and $10^{-12}$ atm, respectively.

\section{PERTINENT OBSERVATIONS AND SUMMARY}

Aside from small compositional differences in major elements that can be attributed to seawater alteration (increasing $\mathrm{K}, \mathrm{Fe}^{+3}$ ), bulk and mineral compositions are consistent throughout the 7.5-meter core of Brazil Basin basalt. Absence of significant chemical fractionation suggests that the core represents one basaltic source. The basalt is characterized by intergranular plagioclase and clinopyroxene, and in the 
R.V. FODOR, J.W. HUSLER, K. KEIL

TABLE 2

Average Compositions of Clinopyroxene Phenocrysts (ph), Microphenocrysts (m), and Groundmass $(\mathrm{g})$ in Basalt from the Brazil Basin $(21-1 ; 22-2 ; 22-5)$ and in a Basaltic Pebble from the São Paulo Plateau (28-3), Western South Atlantic Ocean. Compositions are Averages of 20 to 50 Spot Analyses (in wt \%)

\begin{tabular}{lcccccccc}
\hline & & $21-1$ & \multicolumn{2}{c}{$22-2$} & \multicolumn{2}{c}{$22-5$} & $38-3$ \\
\hline & ph & $\mathrm{m}$ & $\mathrm{g}$ & $\mathrm{m}$ & $\mathrm{g}$ & $\mathrm{m}$ & $\mathrm{g}$ & $\mathrm{ph}$ \\
\hline $\mathrm{SiO}_{2}$ & 52.3 & 51.6 & 48.8 & 52.2 & 49.5 & 51.4 & 49.7 & 52.0 \\
$\mathrm{TiO}_{2}$ & 0.39 & 0.82 & 1.8 & 0.80 & 1.6 & 0.97 & 1.3 & 0.58 \\
$\mathrm{Al}_{2} \mathrm{O}_{3}$ & 3.9 & 4.3 & 6.1 & 4.1 & 4.4 & 4.2 & 3.6 & 2.4 \\
$\mathrm{Cr}_{2} \mathrm{O}_{3}$ & 0.90 & 0.47 & 0.07 & 0.37 & $<.01$ & 0.34 & 0.03 & 0.29 \\
$\mathrm{FeO}$ & 4.6 & 6.6 & 10.9 & 6.9 & 14.7 & 7.7 & 14.3 & 7.0 \\
$\mathrm{MnO}$ & 0.17 & 0.20 & 0.31 & 0.21 & 0.37 & 0.22 & 0.37 & 0.22 \\
$\mathrm{MgO}$ & 17.9 & 17.4 & 14.1 & 16.8 & 12.4 & 16.8 & 13.9 & 16.8 \\
$\mathrm{CaO}$ & 19.4 & 18.0 & 16.6 & 18.1 & 15.7 & 17.8 & 16.1 & 19.4 \\
$\mathrm{Na} 2 \mathrm{O}$ & 0.30 & 0.32 & 0.40 & 0.26 & 0.35 & 0.31 & 0.30 & 0.19 \\
$\mathrm{Total}$ & 99.86 & 99.71 & 99.08 & 99.74 & 99.02 & 99.74 & 98.60 & 98.88
\end{tabular}

Number of Ions on the Basis of $6(0)$

$\begin{array}{lllllllll}\mathrm{Si} & 1.903 & 1.890 & 1.833 & 1.911 & 1.886 & 1.891 & 1.884 & 1.932 \\ \mathrm{Al}^{\mathrm{i} v} & 0.097 & 0.110 & 0.167 & 0.089 & 0.114 & 0.109 & 0.116 & 0.068 \\ \mathrm{Al}^{\mathrm{vi}} & 0.070 & 0.076 & 0.103 & 0.088 & 0.084 & 0.073 & 0.045 & 0.037 \\ \mathrm{Ti} & 0.011 & 0.023 & 0.051 & 0.022 & 0.046 & 0.027 & 0.037 & 0.016 \\ \mathrm{Cr} & 0.026 & 0.014 & 0.002 & 0.011 & - & 0.010 & 0.001 & 0.009 \\ \mathrm{Fe} & 0.140 & 0.202 & 0.342 & 0.211 & 0.468 & 0.237 & 0.453 & 0.217 \\ \mathrm{Mn} & 0.005 & 0.006 & 0.010 & 0.007 & 0.012 & 0.007 & 0.012 & 0.007 \\ \mathrm{Mg} & 0.971 & 0.950 & 0.789 & 0.917 & 0.704 & 0.921 & 0.785 & 0.930 \\ \mathrm{Ca} & 0.756 & 0.706 & 0.668 & 0.710 & 0.641 & 0.701 & 0.654 & 0.772 \\ \mathrm{Na} & 0.021 & 0.023 & 0.029 & 0.018 & 0.026 & 0.022 & 0.022 & 0.014 \\ \mathrm{X} & 2.000 & 2.000 & 1.994 & 1.984 & 1.981 & 1.998 & 2.009 & 2.002 \\ \mathrm{Sum} & 4.000 & 4.000 & 3.994 & 3.984 & 3.981 & 3.998 & 4.009 & 4.002\end{array}$

Molecular End Members

\begin{tabular}{lrrrrrrrr} 
Fs & 7.5 & 10.9 & 19.0 & 11.5 & 25.8 & 12.7 & 24.0 & 11.3 \\
En & 52.0 & 51.1 & 43.9 & 49.9 & 38.8 & 49.6 & 41.5 & 48.5 \\
Wo & 40.5 & 38.0 & 37.1 & 38.6 & 35.4 & 37.7 & 34.5 & 40.2 \\
\hline
\end{tabular}

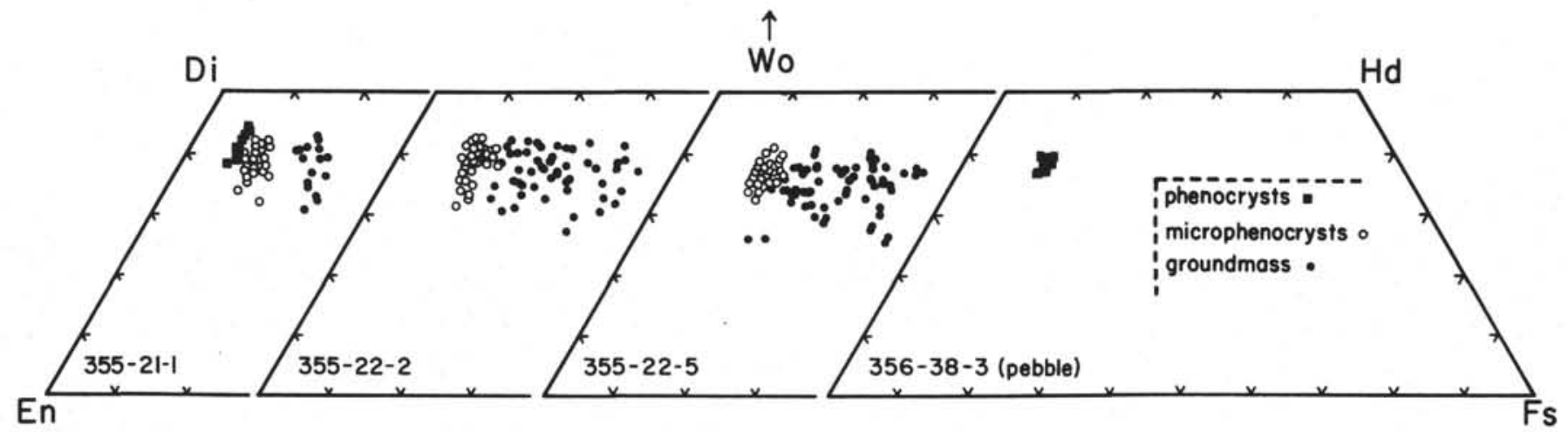

Figure 9. Pyroxene electron-microprobe spot analyses plotted in terms of mole percent enstatite $\left(\mathrm{En} ; \mathrm{Mg}_{2} \mathrm{Si}_{2} \mathrm{O}_{6}\right)$, ferrosilite $\left(\mathrm{Fs}_{3} \mathrm{Fe}_{2} \mathrm{Si}_{2} \mathrm{O}_{6}\right)$, and wollastonite $\left(\mathrm{Wo}_{2} \mathrm{Ca}_{2} \mathrm{Si}_{2} \mathrm{O}_{6}\right)$. Di=diopside $\left(\mathrm{CaMgSi}_{2} \mathrm{O}_{6}\right)$ and $\mathrm{Hd}=$ hedenbergite $\left(\mathrm{CaFeSi}_{2} \mathrm{O}_{6}\right)$. Brazil Basin basalt is indicated by Site 335 (top to bottom of core; 21-1;22-2; 22-5) and the São Paulo pebble by Site 356.

uppermost portions, by minor olivine (relict). Restriction of olivine to the top may indicate an inverted magma chamber where an olivine-enriched bottom portion was the last material to be extruded on the sea floor; magma-chamber zoning, however, is not apparent from the bulk compositions. Whether or not the basalt is a sill or true basement cannot be determined because of the relatively shallow 


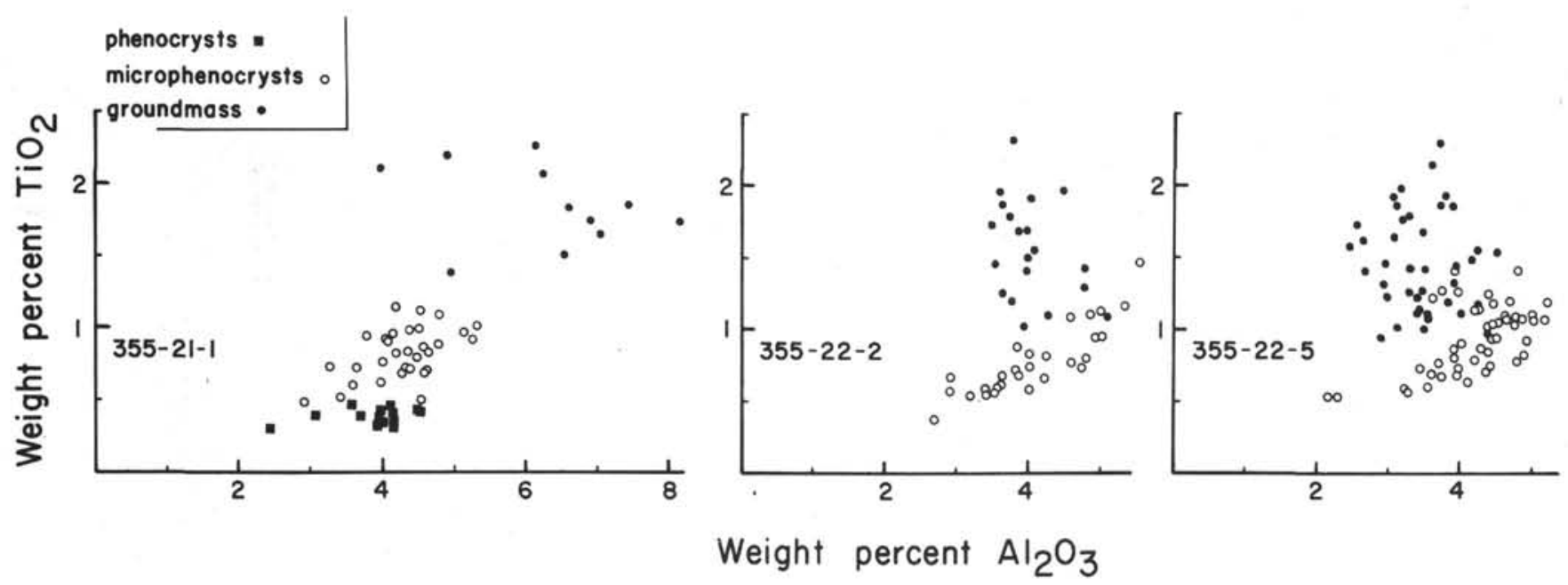

Figure'10. Plot of $\mathrm{TiO}_{2}$ versus $\mathrm{Al}_{2} \mathrm{O}_{3}$ for clinopyroxene electron-microprobe spot analyses of the Brazil Basin basalt (top to bottom of core, $21-1 ; 22-2 ; 22-5)$. High $\mathrm{Al}_{2} \mathrm{O}_{3}$ in pyroxene of Sample $21-1$ may partly be due to alteration of most pyroxene to clay minerals in that sample.

penetration depth and no recovery of upper contact; the age of $78.1 \pm 9$ m.y. (McKee and Fodor, this volume), however, indicates that it is probably basement. Mineral compositions and textural observations show that Mg-rich clinopyroxene crystallization was attended by, and partly succeeded, calcic plagioclase. Groundmass-pyroxene crystallization was attended by intermediate

TABLE 3

Average Compositions of Feldspar Phenocrysts (ph), Microphenocrysts (m), and Groundmass Laths (g) in Basalt from the Brazil Basin $(21-1 ; 22-2 ; 22-5)$ and in a Basaltic Pebble from the São Paulo Plateau (38-3), Western South Atlantic Ocean. Compositions are Averages of 20 to 50 Spot Analyses (in wt\%)

\begin{tabular}{|c|c|c|c|c|c|c|c|c|c|c|c|}
\hline & & $21-1$ & & & 2 & & $22-5$ & & & $38-3$ & \\
\hline & ph & $\mathrm{m}$ & $\mathrm{g}$ & $\mathrm{m}$ & $\mathrm{g}$ & ph & $\mathrm{m}$ & $\mathrm{g}$ & ph & $\mathrm{g}$ & $\mathrm{Hi}-\mathrm{K}^{\mathrm{a}}$ \\
\hline $\mathrm{SiO}_{2}$ & 49.4 & 50.4 & 53.0 & 50.0 & 53.2 & 49.1 & 51.5 & 53.8 & 50.1 & 53.2 & 65.5 \\
\hline $\mathrm{Al}_{2} \mathrm{O}_{3}$ & 32.1 & 30.7 & 29.4 & 30.7 & 28.5 & 31.6 & 30.0 & 28.7 & 31.9 & 29.7 & 18.3 \\
\hline $\mathrm{FeO}$ & 0.73 & 0.85 & 1.0 & 0.83 & 1.3 & 0.77 & 0.94 & 1.3 & 0.59 & 0.95 & 0.77 \\
\hline $\mathrm{MgO}$ & 0.43 & 0.47 & 0.51 & 0.44 & 0.41 & 0.38 & 0.45 & 0.43 & 0.23 & 0.15 & 0.09 \\
\hline $\mathrm{CaO}$ & 16.2 & 14.8 & 13.0 & 15.1 & 11.8 & 16.3 & 13.3 & 11.1 & 15.0 & 12.1 & 0.92 \\
\hline $\mathrm{Na}_{2} \mathrm{O}$ & 2.4 & 3.2 & 3.2 & 3.0 & 4.8 & 2.5 & 3.9 & 5.3 & 2.8 & 4.2 & 1.9 \\
\hline $\mathrm{K}_{2} \mathrm{O}$ & 0.04 & 0.06 & 0.11 & 0.07 & 0.09 & 0.04 & 0.06 & 0.09 & 0.14 & 0.34 & 12.8 \\
\hline Total & 101.30 & 100.48 & 100.22 & 100.14 & 100.10 & 100.69 & 100.15 & 100.72 & 100.76 & 100.64 & 100.28 \\
\hline
\end{tabular}

Number of Ions on the Basis of $32(0)$

\begin{tabular}{|c|c|c|c|c|c|c|c|c|c|c|c|}
\hline $\mathrm{Si}$ & 8.956 & 9.191 & 9.600 & 9.156 & 9.682 & 8.969 & 9.387 & 9.718 & 9.094 & 9.609 & 11.969 \\
\hline Al & 6.859 & 6.598 & 6.276 & 6.625 & 6.113 & 6.803 & 6.444 & 6.110 & 6.824 & 6.322 & 3.941 \\
\hline $\mathrm{Fe}$ & 0.111 & 0.130 & 0.151 & 0.127 & 0.198 & 0.118 & 0.143 & 0.196 & 0.090 & 0.143 & 0.118 \\
\hline $\mathrm{Mg}$ & 0.116 & 0.128 & 0.138 & 0.120 & 0.111 & 0.103 & 0.122 & 0.116 & 0.062 & 0.040 & 0.025 \\
\hline $\mathrm{Ca}$ & 3.147 & 2.891 & 2.523 & 2.962 & 2.301 & 3.190 & 2.597 & 2.148 & 2.917 & 2.341 & 0.180 \\
\hline $\mathrm{Na}$ & 0.844 & 1.131 & 1.124 & 1.050 & 1.694 & 0.885 & 1.378 & 1.856 & 0.985 & 1.471 & 0.673 \\
\hline K & 0.009 & 0.014 & 0.025 & 0.016 & 0.021 & 0.009 & 0.014 & 0.021 & 0.032 & 0.078 & 2.984 \\
\hline Z & 15.815 & 15.789 & 15.876 & 15.781 & 15.795 & 15.772 & 15.831 & 16.542 & 15.918 & 15.931 & 15.910 \\
\hline $\mathrm{x}$ & 4.227 & 4.294 & 3.961 & 4.290 & 4.325 & 4.305 & 4.254 & 4.337 & 4.086 & 4.073 & 3.980 \\
\hline Sum & 20.042 & 20.083 & 19.837 & 20.056 & 20.120 & 20.077 & 20.085 & 20.165 & 20.004 & 20.004 & 19.890 \\
\hline \multicolumn{12}{|c|}{ Weight Percent End Members } \\
\hline An & 79.7 & 72.8 & 69.9 & 74.4 & 58.7 & 79.1 & 66.4 & 54.8 & 75.2 & 61.5 & 4.7 \\
\hline $\mathrm{Ab}$ & 20.1 & 26.8 & 29.4 & 25.2 & 40.8 & 20.7 & 33.2 & 44.7 & 24.0 & 36.4 & 16.7 \\
\hline Or & 0.2 & 0.4 & 0.7 & 0.4 & 0.5 & 0.2 & 0.4 & 0.5 & 0.8 & 2.1 & 78.6 \\
\hline
\end{tabular}

${ }^{\mathrm{a} G r o u n d m a s s ~ i n t e r s t i t i a l ~ f e l d s p a r . ~}$ 


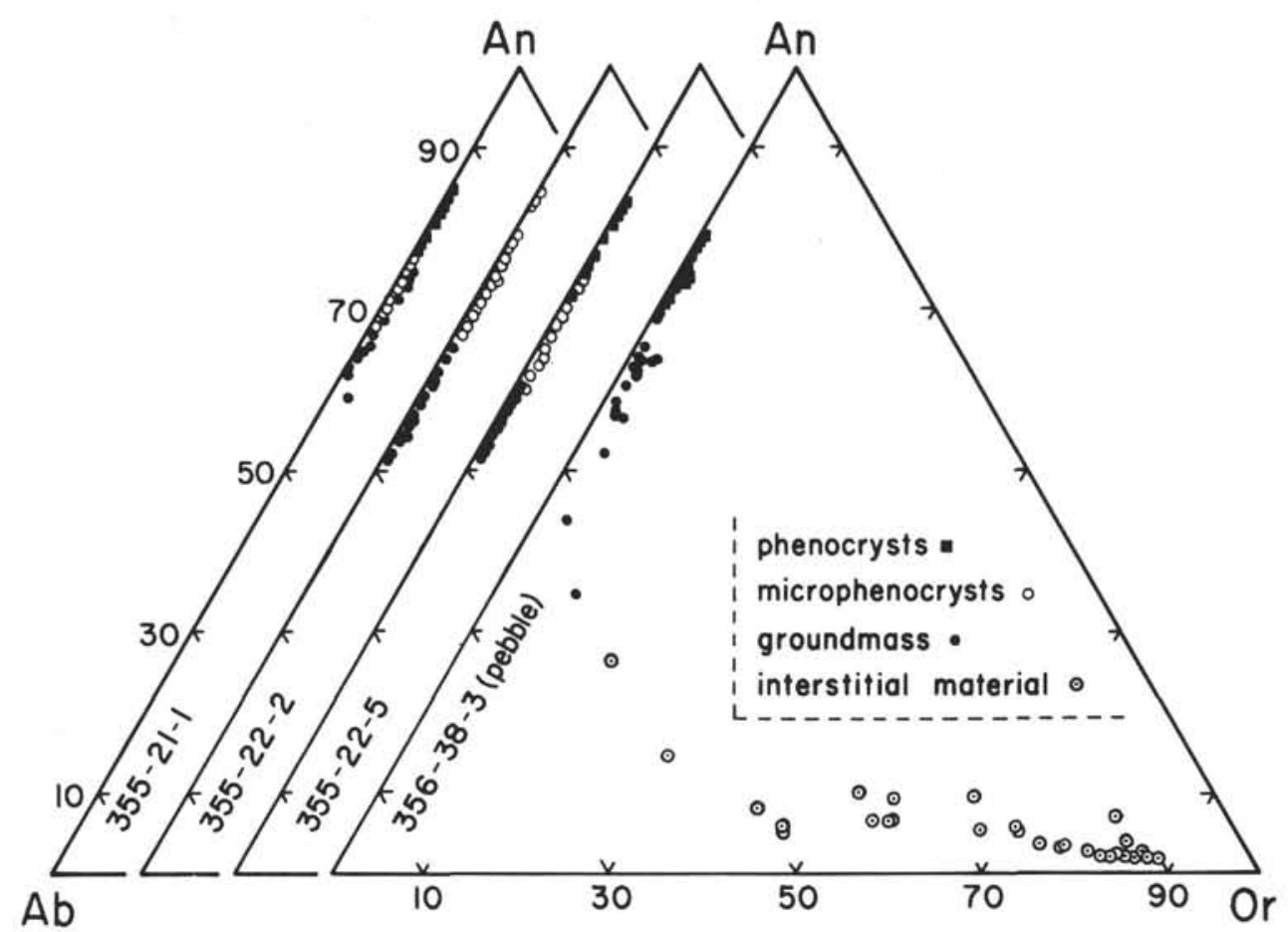

Figure 11. Ternary feldspar diagrams where individual feldspar electron-microprobe spot analyses are plotted in terms of weight percent anothite $\left(\mathrm{An} ; \mathrm{CaAl}_{2} \mathrm{Si}_{2} \mathrm{O}_{8}\right)$, albite $(\mathrm{Ab}$; $\mathrm{NaAlSi}_{3} \mathrm{O}_{8}$ ), and orthoclase (Or; $\left.\mathrm{KAlSi}_{3} \mathrm{O}_{8}\right)$. Brazil Basin basalt is indicated by Site 355 (top to bottom of core, 21-1; 22-2; 22-5) and the São Paulo pebble by Site 356.

TABLE 4

Average Compositions of Titaniferous Magnetite and Ilmenite in Basalt from the Brazil Basin (22-5) and in a Basaltic Pebble from the São Paulo Plateau (38-3) Western South Atlantic Ocean. Compositions are Averages of $\mathbf{3 0}$ to $\mathbf{5 0}$ Spot Analyses (in wt \%)

\begin{tabular}{|c|c|c|c|c|c|}
\hline & \multicolumn{2}{|l|}{$22-5$} & \multicolumn{2}{|c|}{$38-3$} & \multirow[b]{2}{*}{ ilm $^{a}$} \\
\hline & $\mathrm{mt}$ & $\mathrm{mt}$ & ilm & (Range) & \\
\hline $\mathrm{SiO}_{2}$ & 0.95 & 1.1 & 0.77 & & 1.0 \\
\hline $\mathrm{TiO}_{2}$ & 22.4 & 17.3 & 47.8 & $(46.1-51.9)$ & 47.5 \\
\hline $\mathrm{Al}_{2} \mathrm{O}_{3}$ & 3.2 & 1.7 & 1.1 & $(0.75-1.5)$ & 1.6 \\
\hline $\mathrm{Cr}_{2} \mathrm{O}_{3}$ & 0.03 & 0.10 & 0.06 & & 0.01 \\
\hline $\mathrm{V}_{2} \mathrm{O}_{3}$ & 0.27 & 0.57 & 0.27 & & 0.18 \\
\hline $\mathrm{FeO}$ & 67.7 & 71.5 & 45.2 & $(37.2-46.1)$ & 45.2 \\
\hline $\mathrm{MnO}$ & 0.74 & 0.26 & 0.88 & & 0.57 \\
\hline $\mathrm{MgO}$ & 0.88 & 0.91 & 2.4 & $(1.4-3.1)$ & 2.6 \\
\hline $\mathrm{CaO}$ & 0.71 & 0.37 & 0.16 & & 0.31 \\
\hline $\mathrm{ZnO}$ & 0.29 & 0.02 & 0.15 & & 0.09 \\
\hline Sum & 97.17 & 93.83 & 98.79 & & 99.06 \\
\hline \multicolumn{6}{|l|}{ Recalculated } \\
\hline $\mathrm{FeO}$ & 48.7 & 43.8 & 38.4 & & 38.2 \\
\hline $\mathrm{Fe}_{2} \mathrm{O}_{3}$ & 21.1 & 30.8 & 7.5 & & 7.7 \\
\hline Total & 99.27 & $96.93^{b}$ & 99.49 & & 99.96 \\
\hline Usp (mol \%) & 66.6 & 51.4 & - & & - \\
\hline Hem & - & - & 8.1 & & 8.4 \\
\hline
\end{tabular}

${ }^{\mathrm{a}}$ Coexisting with magnetite.

${ }^{b_{\text {Total }}}$ may be low due to more $\mathrm{Fe}$ being $\mathrm{Fe}^{3+}$ than calculated stoichiometrically. plagioclase, but preceded titaniferous magnetite. Bulk compositions border between quartz and olivine tholeiites. The compositions show that ocean-ridge basalt was essentially the same in upper Cretaceous time, shortly after initial rifting of the South Atlantic Ocean, as many basalts that were only recently erupted at the Mid-Atlantic Ridge (Table 1). Compositionally, such material represents extensive melting of mantle material at relatively shallow depth (e.g., Kay et al., 1970). Consistent compositions over at least $80 \mathrm{~m} . \mathrm{y}$. indicate no major temperature changes beneath the Mid-Atlantic Ridge.

The São Paulo Plateau basaltic pebble (recovered from Cretaceous sediments) has been extensively altered by seawater. Concentrations of certain elements, however, such as $\mathrm{K}, \mathrm{Rb}, \mathrm{Ba}$, and $\mathrm{Sr}$, are indicative of initial alkalic-basalt characteristics, somewhat modified by alterations, and indicate that the pebble was not typical ocean-ridge basalt. This suggestion is supported by the relatively high $\mathrm{K}$ in plagioclase and the interstitial alkali feldspar, which are characteristic of alkalic basalt, or alkalic basalt transitional to tholeiite.

The large size $(3.5 \mathrm{~cm})$ of the pebble precludes the possibility of long transport (i.e., continental source) and suggests that its source was local. In addition, substantial amounts of basaltic pebbles in conglomerites (Figure 2) associated with mudstones and graded zones underlying the pebble indicate extensive deposition of coarse material from a local source during Santonian time. The most likely source 
for such slump deposits is the nearby São Paulo Ridge, of east-west trending feature that bounds the São Paulo Plateau on the south (see, for example, Leyden et al., 1971).

The implications, then, are that the São Paulo Ridge (the presumed source of the pebble) is not composed of typical ocean crust (tholeiitic basalt), at least in part. It more closely resembles oceanic alkalic basalt (or transitional basalt), which almost invariably is associated with seamounts and volcanic islands (e.g., Engel et al., 1965) and commonly represents posttholeiitic activity. This in turn, suggests that the eastwest-trending São Paulo Ridge bordering the São Paulo Plateau may be composed of a continuous or semicontinuous chain of volcanos that developed during early Cretaceous time along the east-west fracture zone that bounds the Rio Grande Rise on the north, or by a "hot spot" on the Mid-Atlantic Ridge.

\section{NOTE ADDED IN PROOF}

The following analyses have been provided by Dr. Roman Schmidt for Samples 355-22-5, $120 \mathrm{~cm}$, using INAA techniques:

$\begin{array}{lr}\text { Sc }(p p m) & 43.9 \\ \mathrm{Hf} & 3.4 \\ \mathrm{La} & 3.5 \\ \mathrm{Ce} & 14.0 \\ \mathrm{Sm} & 4.0 \\ \mathrm{Eu} & 1.6 \\ \mathrm{~Tb} & 1.1 \\ \mathrm{Yb} & 4.0 \\ \mathrm{Lu} & 0.59\end{array}$

\section{ACKNOWLEDGMENT}

This work was supported in part by the National Aeronautics and Space Administration, Grants NGL 32-004063 and NGL 32-004-064 (K. Keil, Principal Investigator).

\section{REFERENCES}

Bass, M.N., Moberly, R., Rhodes, M.J., Shih, C., and Church, S.E., 1973. Volcanic rocks cored in the Central Pacific, Leg 17, Deep Sea Drilling Project. In Winterer, E..L., Ewing, J..L., et al., Initial Reports of the Deep Sea Drilling Project, Volume 17, Washington (U.S. Government Printing Office), p. 429.
Bence, A.E. and Albee, A.L., 1968. Empirical correction factors for the electron microanalysis of silicates and oxides: Jr. Geol. v. 76, p. 382.

Buddington, A.F. and Lindsley, D.H., 1964. Iron-titanium oxide minerals and synthetic equivalents: Jr. Petrol. v. 5, p. 310 .

Engel, A.E., Engel, C.G., and Havens, R.G. 1965. Chemical characteristics of oceanic basalts and the upper mantle: Geol. Soc. Am. Bull., V. 76, p. 719.

Fodor, R..V., Keil, K., and Bunch, T.E., 1972. Mineral chemistry of volcanic rocks from Maui, Hawaii: Fe-Ti oxides: Geol. Soc. Am. Abstracts with Program, v. 4, p. 507.

Fodor, R.V., Keil, K., and Bunch, T.E., 1975. Contributions to the mineral chemistry of Hawaiian rocks IV. Pyroxenes in rocks from Haleakala and West Maui volcanoes, Maui, Hawaii. Contrib. Mineral. Petrol., v. 50, p. 173.

Hart, R.A., 1970. Chemical exchange between sea water and deep-ocean basalts: Earth Planet. Sci. Lett., v. 9, p. 269.

Hart, S.R., Erlank, A.J., and Kable, E.G.D., 1974. Sea floor basalt alteration: some chemical and $\mathrm{Sr}$ isotope effects: Contrib. Mineral. Petrol., v. 44, p. 219.

Kay, R., Hubbard, N.J., and Gast, P.W., 1970. Chemical characteristics and origin of oceanic ridge volcanic rocks: J. Geophys. Res., v. 75, p. 1585.

Keil, K., Fodor, R.V., and Bunch, T.E., 1972. Contributions to the mineral chemistry of Hawaiian rocks II. Feldspars in rocks from Haleakala and West Maui volcanoes, Maui, Hawaii: Contrib. Mineral. Petrol., v. 37, p. 253.

Leyden, R., Ludwig, W.J., and Ewing, M. 1971. Structure of the continental margin off Punta del Este, Uruguay and Rio de Janeiro, Brazil: Am. Assoc. Petrol. Geol. Bull. v. 55 , p. 2161 .

Matthews, D.H., 1971. Altered basalts from Swallow Bank, an abyssal hill in the NE Atlantic and from a nearby seamount: Phil. Trans. Roy. Soc. London, v. 268, p. 551.

Melson, W.G. and Thompson, G. 1971. Petrology of a transform fault zone and adjacent ridge segment: Phil. Trans. Roy. Soc. London, v. 268, p. 423.

Melson, W.G and Thompson, G., 1973. Glassy abyssal basalts, Atlantic sea floor near St. Paul's rocks: petrography and composition of secondary clay minerals: Geol. Soc. Am. Bull., v. 84, p. 703.

Pitman, W.C., Larson, R.L., and Herron, E.M., 1975. Magnetic lineations of the oceans: Geol. Soc. Am. Map.

Stewart, R.J., Natland, J.G., and Glassley, W.R., 1973. Petrology of volcanic rocks recovered on DSDP Leg 19 from the North Pacific Ocean and the Bering Sea. In Initial Reports of the Deep Sea Drilling Project, Volume 19: Washington (U.S. Government Printing Office), p. 615. 